\title{
Benefit-Cost Analysis of flood management, a case study of Jammu and Kashmir
}

\author{
Kowser Ali Jan \\ Ph.D Research Scholar \\ Department of Economics \\ Annamalai University \\ 608002
}

\author{
Dr R. Balaji \\ Assistant Professor \\ Department of Economics \\ Government Arts College \\ Ariyalur- 621713
}

\begin{abstract}
A disaster hurts those affected. It also spares many in the affected areas, yet those spared may be indirectly affected. The analytical framework of prevention and coping has proved helpful in many circumstances. Historically and currently, there has been limited quantitative information available on flood management in Jammu and Kashmir. This study focuses on the cost-benefit analysis (CBA) of flood management by District Disaster Management Kulgam, and the assessment is based on secondary pooled data collected from government offices, NGOs, published Journals, and local and national newspapers. It also described the scenario, the approach adopted, and the sources of flood damage cost information. The estimated total benefits account for 78686.18 lakh of rupees, and that of total costs account for 2218.75lakh of rupees. The Benefit-Cost ratio greater than one ( $>1)$ shows that Flood Management in District Kulgam was economically feasible and successfully managed. The State of Jammu and Kashmir takes essential prevention and management measures to bring down the damages due to floods to significant status.
\end{abstract}

\section{Keywords Cost-benefit analysis, nature, flood management \\ 1. Introduction}

Change is the law of nature. It is a continuous process that uninterruptedly involves phenomena, big and small, material and non-material, making our physical and socio-cultural environment. It is a process existing worldwide with daily variation in terms of amount, intensity, and scale. Change can be a gradual or slow action like the evolution of landforms, and it can be as fast and swift as volcanic eruptions, tsunamis, earthquakes, flash floods, etc. Except for inevitable floods triggered by dam collapse or landslides, floods are climate phenomena determined by the circumstances of geology, geomorphology, relief, soil, and vegetation (LA Naylor, 2017). The World becomes highly vulnerable to natural hazards. While floods are natural events, the river basins' condition has changed dramatically about human activities and human interference in biological processes, such as changes in drainage patterns resulting from urbanization, agricultural practices, or deforestation (Zhang, 2016). Floods are relatively sudden in occurrences and often occur in well-identified regions and within the expected time in a year. Floods commonly occur when surface run-off water exceeds the river channels' carrying capacity and streams and flows into the adjacent low-lying floodplains. Floods in the South, Southeast, and East Asian countries, particularly in China, India, Pakistan and Bangladesh, are frequent and equally disastrous. Various states of India face heavy loss of lives and property due to recurrent floods in the past decade (Dewan, 2013)

On September 6, 2014, Jammu and Kashmir saw gigantic floods that left thousands of people abandoned inside their houses. Two hundred fifty towns across Kashmir had been affected, one hundred sixty individuals had passed on, and many domiciliates were bore away (Bansal, 2017). One can scarcely observe the lofty Chinars, the fragrant pine trees, and the rich sobbing willows that gave harbour to those slammed by the destinies. The charming magnificence of Mughal gardens, reviving springs, and impressive cascades lament the condition of the destroyed land, the contaminated streams, and the enduring individuals. River Jhelum, flowing five feet above 
the danger mark in 2014, had inundated over one hundred villages (Sandrp, 2015). The most affected districts were Anantnag, Kulgam, Shopian, Pulwama, Bandipora, Ganderbal, Srinagar, and Badgam. The condition heightened as virtually all the significant emergency medical institutions were unfavourably influenced and delivered dead. Almost ten days after the floods, three significant healthcare facilities in the city stayed shut for patients, while two partially continued their administrations to specific patients (outpatient care just) (The 2014 Kashmir Flood, GK). The floods straightforwardly influenced more than two thousand six hundred villages in the State and turned down thirty per cent of the town zones. The water levels ascended to twenty feet in the city while numerous towns were sliced up off because of the decimation of the main extensions and streets driving into these towns (Yatoo et al., 2018). The state government declared a calculated loss of rupees one trillion because of the floods, with housing sphere deprivations of thirty thousand crores and business sector losses of seventy thousand crores (Economics Survey Kashmir 2015).

\section{Flood management in Jammu and Kashmir}

Despite the gains ground in science and technology, humanity cannot still cope with nature's anger. The natural order of life is interrupted by destruction. It has challenges and adverse health effects. We can not avoid disaster entirely, but flood management is necessary. The flood's aftermaths can be prevented by taking practical action strategies for disaster prevention. The measures to reduce the flood catastrophe will involve. 1. Design strategies to resilience these risks and enforce them. 2. A solid plan for post-flood recovery and reduction (Hans de Moel, 2013).

As mentioned above, heavy rains in September 2014 caused devastating floods and landslides in UT of Jammu and Kashmir, affecting some parts of Jammu and most parts of Kashmir valley. More than seven hundred villages remained submerged. Srinagar, the capital city, got submerged. 6.48 lakh hectares of Agriculture/horticulture land got affected. About three lakh houses got fully or partially damaged (Economic Survey JK 2014-15). The case of the Kulgam district was not different. The situation warrants a close probe to identify the factors at work from a policy perspective - the various research issues delineated below would provide a rationale for the proposed study in the Kulgam district. The flood devastation is severely affected the Kulgam district. In light of the above reflections, the present researcher intends to analyze flood management in-depth. Accounting for the damage assessment and documenting administration records in management and rehabilitation works gives specific policy directions.

\section{Cost-Benefit Analysis.}

The United States Flood Control Act of 1936, which specified the participation of the Federal Government of the United States were the first used CBA in the World in flood management to control flooding on major rivers of the country. According to that, flood management is economically feasible "if the benefits to whomsoever they accrue are more than the estimated costs" (Associated Programme on Flood Management et al., 2007).

\section{The essence of CBA lies in:}

(i) To identify the items of benefit and cost in the flood management from an economic point of view, i.e., allowing all the benefits accruing to and all the costs incurred by the private or public sector;

(ii) Adopting appropriate prices for measuring the benefits and costs in monetary terms; and

(iii) To adjusting the future prices of costs and benefits to present values to make them comparable. 
Because benefits and costs are stemming from many different effects, a systematic procedure is required to make sure that each is considered and evaluated properly. The practice so far has been to include only the direct effects, even though some other effects are also being taken into account.

This study has three goals. The first is to analyze the direct and indirect benefits Loss due to flood] incurred due to the 2014 flood in Kulgam district. In the case of a flood management project, direct benefits include the reduction in physical damage. Thus, flood damage to crops, cattle, houses, commercial and industrial buildings, infrastructure etc., avoided because of construction of embankments, flood retention reservoirs or flood warning systems, are direct benefits. Indirect benefits may occur by avoiding disruption to business, transport networks and public services and by avoiding the costs of accident and emergency response and recovery. (Associated Programme on Flood Management et al., 2007).

\subsection{Classification of Direct and Indirect Benefits to the society through Cost of Damage Due to Flood Approach}

\begin{tabular}{|c|l|l|}
\hline $\begin{array}{c}\text { S. } \\
\text { No. }\end{array}$ & Type of Benefits & \multicolumn{1}{|c|}{ Components } \\
\hline 1 & $\begin{array}{l}\text { Direct benefits: } \\
\text { i) Tangible Costs } \\
\text { ii) Intangible costs }\end{array}$ & $\begin{array}{l}\text { Physical damage to property: Housing, Agriculture, } \\
\text { Commercial Buildings and Livestock }\end{array}$ \\
\cline { 3 - 3 } & $\begin{array}{l}\text { a) Primary: Loss of human life } \\
\text { b) Secondary: Illness of flood victims }\end{array}$ \\
\hline 2 & Indirect benefits: & $\begin{array}{l}\text { a) Primary: Disruption of traffic and trade } \\
\text { b) Secondary: Reduced purchasing power }\end{array}$ \\
\hline
\end{tabular}

The 2nd goal of the study is to compute the direct and indirect costs of flood management in the Kulgam district after the 2014 flood. The State Government adopted many methods to tackle future disasters in the district. As benefits, the costs of flood management projects can be defined as primary and secondary. However, cost estimation is comparatively more exact and easy. Construction measures and their prices are at the core of cost analysis. One method for estimating costs is to use a comprehensive checklist of cost items readily available in the professional literature. However, any such list should be updated and modified in the light of the latest thinking and local requirements. Thus, the cost estimates are based on actual market prices even if these are distorted and not suitable for CBA (Associated Programme on Flood Management et al., 2007).

\subsection{Types of Costs.}

\begin{tabular}{|l|l|}
\hline Structural: Mitigation costs & Non-structural: Adaptation costs \\
\hline Reshaping of land surface & Flood defense \\
Protection from erosion & Forecasting \\
Levees, dykes, floodwalls & Warning \\
Dams and reservoirs & Floodproofing \\
Flood ways and diversion works & Evacuation \\
\hline
\end{tabular}




\begin{tabular}{|l|l|}
\hline Polders and fills & Relocation \\
Drainage works & \\
\hline
\end{tabular}

The study's third and last goal is to compare the cost and benefit of flood management in the Kulgam district. Cost-benefit Analysis is used to compare the reduced risk due to measure implementation with the costs of implementing the measures. The probability of a weather event occurring does not change by implementing measures; however, the propagation and related damage cost do.

\section{Data construction}

The study is based on the secondary pooled data on the cost and benefits of the flood from the publishing record of District Disaster Management plan Kulgam 2017-18, research journals, Government offices, and newspapers. The data was treated for a cost-benefit analysis to derive the necessary results - the Analysis based on past damage data. In the case of flood management in the Kulgam district, important information was available as the number of damaged houses during the 2014 flood, relief amount, construction on river banks, damaged roads, etc. However, some data, particularly on the social impact, were lacking, and the Analysis followed the pooled data approach based on estimates of past impacts. Impacts assessed comprise direct and indirect economic impacts. The method of cost-benefit Analysis follows these steps: 1. An economic valuation of damage costs. 2. Identification of measures. 3. Cost-estimation of measure implementation. 4. Reduced risk costs as a result of measure implementation. 5. Cost-benefit analysis. (WMO Report, 2007).

\section{Limitations}

This study focused on the estimation of the effects of measures for flooding and their related benefits. There is no intention to list all available measures to reduce the risk of flooding, as this is highly dependent on local conditions. This analyze is the first of its form in the Kulgam district while using the CBA model for flood management. Since relevant in-data has been provided using secondary data, the quality of the results from the case study fluctuates accordingly.

\section{Analysis of Benefits of Flood Management in the Kulgam District.}

The Vishaw tributary of River Jhelum flowing through Kulgam District caved embankments and eroded habitants, healthcare system, schools, Govt. offices, and many other buildings and infrastructure. The most significant tangible cost category which was hit badly was considered to be housings. Most of the houses were made with bricks and cement. On average, 2705 households got damaged during the 2014 floods in 22 villages, according to rapid assessment report 2014 and District Disaster Management Plan Kulgam (2017-18).

\subsection{Direct Benefits}

\subsubsection{Damage of Houses and Assets}

The Centre for Science and Environment of India stated that Kashmir floods were caused by mismanagement, heavy rains, unplanned urbanization, and lack of preparedness. (Malay Das, 2019). There is an African proverb, "where water is the boss, there must the land obey," which is perfectly suited to our valley. The illegal construction on river banks will pave you more risk when you disobey the water bodies and their nature. The modern architecture of the housing sector in the valley doesn't suit the climatic conditions. The housing damage in district Kulgam in the 2014 floods was devastating. The housing building's total damage cost has been estimated with rupees 9950 lakh calculated on the current market price of infrastructure material. In contrast, the total cost of damages of assets (durable and nondurable assets) has been calculated 
as 552 lakh of rupees. Flood damage has the potential to step up into a grievous emergency if not treated immediately.

\subsubsection{Agriculture}

Flood 2014 was one of the devastating floods in the history of Kashmir as mentioned above. The study revealed that human interference and non-eco-friendly development in Jammu and Kashmir were the main reason for such disaster(MehrajUd Din Waza, 2018). Agriculture is the mainstay of the Kulgam district. Almost $80 \%$ of people directly depend on agriculture for their livelihood. It had seen that mostly the villages along the Nallai Veshaw River were suffering from river erosion, whereas other villages are suffering from flooding, inundation, and sedimentation. The findings of the total cost of agricultural land damage, loss of economic trees, crops, and apple cultivation revealed: Out of 2705 affected households, 37.5 percent are large farmers, and 62.5 of small or marginal farmers were affected by the flood. The total estimated cost of damage of land is 55,785 lakh of rupees. Since the August- September season for apples in Kashmir has been considered the ripe growth season, the Floods of 2014 hit this sector very hard. The cost of apple loss is figured by adding the cost of apple loss of big cultivators with that of small cultivators, and it is figured as 2123.5 lakh of rupees. Regarding loss of crops, rice, wheat, maize, and vegetables, the estimated total cost of loss of crops accounts for rupees 1,089 lakhs.

Animal husbandry is the second-largest source of income after agriculture in the district. A wide number of livestock deaths occurred because of the flood, and unidentified diseases after the flood impacted the living standard of people. There was also infrastructure damage to cow yards in the vicinity. The estimated total cost of loss of livestock and livestock infrastructure accounts for rupees 1194 lakhs.

\subsubsection{Loss of Commercial Buildings}

Since the district has a large rural population, there is not much commercial property in the villages. But 2014 flood-hit small business shops as well. Commercial businesses contain many kinds of property, inventory, machinery, equipment, products, and goods. The total number of commercial buildings damaged was 1190 lakh. 55.62 percent of the households, as per data available which were not attached with commercial activities. So the commercial business affected by the 2014 flood was less.

\subsection{Indirect Benefits}

Indirect benefits come from the effects of technological linkages of a Management project. These could be described as "Management externalities." Flood management projects may benefit users of transportation by reducing interruptions to traffic.

\subsubsection{Reduction in Purchasing power.}

The devastation caused by the 2014 flood was colossal. It destroyed everything that came to its way-residential houses, schools, colleges, hospitals, paddy fields, orchards, government establishments, businesses, etc. It has depicted thousands of people roofless and jobless. The destruction around has left the entire society traumatized (S Tabish, 2015). The socioeconomic dimension analysis leads to the distribution of income among victims. The flood has destroyed the sources of income of the families. The income of households reduced to half when comparing pre-flood income. The total cost reduction in purchasing power is accounted for 147.2 lakhs of rupees in the district. The cost reduction in purchasing power in income group (A ) is estimated as Rs.41.7 lakhs (20.6), and it is 105.5 lakhs of rupees in case of income Group B. Before the flood, the monthly income ranges from 10000> (A) to 20000>(B).

\subsubsection{Transport}


Flooding of roads can cause physical damages and interruptions in both passenger and freight traffic. In district Kulgam, main roads were blocked by landslides. Roads connecting the Kulgam town with rural areas of the district were washed away by floodwater. It is not easy to attain reliable values for flooded roads. Current values for damages to roads have been maintained by using the restoring cost data from Jammu and Kashmir Home Department. The total cost of damaged roads and bridges accounted for 802 lakh of rupees. It indicates that the main roads of Kulgam district were washed away by floodwater in 2014, resulting in interrupted traffic for two to three years in the district.

\section{Analysis of the direct and indirect costs incurred due to Flood in Kulgam District.}

As benefits, the costs of a project can also be defined as primary and secondary. However, the cost estimate is relatively more accurate and easy. Construction measures and their prices are at the core of cost analysis. One method for estimating costs is to use a comprehensive checklist of cost items readily available in the professional literature. However, any such list should be updated and modified in the light of the latest thinking and local requirements. Thus, the cost estimates are based on actual market prices.

\subsection{Primary Costs}

\section{Prime Minister's National Relief Fund (PMNRF)}

The government and key stakeholders were engaged to restore the livelihood of the population. Alternative livelihood strategies took place in different areas of District Kulgam. Prime Minister's relief fund was one of the successful rehabilitation plans for the new construction of damaged houses.

\subsubsection{Reconstruction of damaged houses:}

The Sanction rate of reconstruction of fully damaged pucca and kutcha houses was Rs.1 lakh and Rs.50,000/- per household, respectively. The rate of reconstruction of Partially damaged pucca houses and kutcha houses was 25,000/- and Rs.5,000/- each, respectively. Altogether, Rs.565 crore was released for Jammu and Kashmir to reconstruct 21,088 fully damaged Pucca \& Kutch houses and 1,97,652 severely and partially damaged pucca and kutcha houses (Prime Minister's National Relief Fund, n.d.). The total amount released for Kulgam district is four crores 23 lakh. However, there is a huge gap between damaged cost and the relief incentive by government.

\subsubsection{Infrastructures costs for Disaster Management}

Because of flood mitigation, many govt agencies took steps to construct approach walls, reshape land surface, protect from erosion, levees, dykes, and floodwalls in district Kulgam. The data we used were collected from Irrigation and Flood Control Department Jammu and Kashmir. Infrastructure cost is estimated as 700 lakh of rupees.

\subsubsection{Cost of floodways and diversion works}

In the Kulgam district, the general requirement was drainage systems to cope with rainfall. Flooding in Nallah Vishow often results in overloading in the small canals leading to overflows. Irrigation and Flood Control Department, Jammu and Kashmir constructed and restored canals to cope with further damage in the future. The data were gathered from Irrigation and Flood Control department Jammu and Kashmir. The total restoration cost accounts for rupees 862 lakh, and there is a need for further diversions in the NallahVishow and restoration of these canals from time to time.

\subsubsection{Flood Warning system}


The Flood Control Department has initiated to development of a flood monitoring station in the vicinity of Nihama. In this station, a rain gauge and other tools will help deal with anticipating floods. 4 number Gauges to install on the various Nallahs to know flood discharges. Since there was no cost-related information available, as per the District Disaster Management Plan (2017-18), the vicinity covered 5 Kanals of land, which costs 25 lakh as per market price.

\subsection{Secondary Costs}

\subsubsection{Allocation of Costs in Multiuser disaster Management.}

The Kulgam District has been divided into eight beats of the flood. Therefore Flood Control Division Kulgam keeps the availability of flowing items as per the need. The allocation of costs in Multiuser disaster Management among different items and total cost for Multipurpose disaster Management is estimated as 192.75 lakh of rupees.

5.2.2 Cost of Availability of Emergency drugs. The most significant diseases experienced during a flood are diarrhea, fever, and skin diseases. To cope with these types of diseases in the future, the Local Flood Zonal Committee keeps the Medicines available. The cost of the availability of emergency drugs allotted is 11.1 lakh of rupees

\section{Cost-Benefit Analysis}

The findings of Cost-benefit Analysis reveal: There are 11 components in the estimation of benefits of CBA. The estimated total benefits account for 78686.18 lakh of rupees. Likely, there are six components in the estimation of costs of CBA. The estimated total costs account for 2218.75lakh of rupees. The estimated Benefit-Cost Ratio is 35.5:1. The CBA result shows that Flood Management in District Kulgam was economically feasible and successfully managed. The State takes essential prevention and management measures to bring down the damages due to floods to significant status. To protect the district from another disaster, govt should pump more money into its disaster security.

\section{Conclusion}

As discussed under various perspectives, it is clear from the study that the 2014 floods hit the economic status of people's livelihoods in the district Kulgam badly. Among the categories of property damaged, Land value damage is the highest. All the households own apple cultivation land; there was significant damage to the farmers. The study region's average financial assistance was one lakh per household, which was very less compare to the damages caused. The study has further demonstrated that the effects of floods in one sector could also affect other social sectors. In the Agriculture sector, the loss of crops led to the reduction of purchasing power of households. Furthermore, the business sector suffered through interrupted traffic for years due to road damage connecting with the district headquarter.

\section{References}

Ranking sources of uncertainty in flood damage modelling: A case study on the cost-benefit analysis of a flood mitigation project in the Orb Delta, France-Saint-Geours-2015Journal of Flood Risk Management-Wiley Online Library. (n.d.). Retrieved April 3 2021, from https://www.onlinelibrary.wiley.com/doi/full/10.1111/jfr3.12068 
Agrawal, S., Gopalakrishnan, T., Gorokhovich, Y., \& Doocy, S. (2013). Risk Factors for Injuries in Landslide- and Flood-Affected Populations in Uganda. Prehospital and Disaster Medicine, 28, 1-8. https://doi.org/10.1017/S1049023X13000356

Cost-benefit analysis: Its usage and critiques-Hwang-2016-Journal of Public Affairs-Wiley Online Library. (n.d.). Retrieved April 3 2021, from https://onlinelibrary.wiley.com/doi/full/10.1002/pa.1565?casa token=4zj n XSXKEAAAA A\%3AkzSqKiC5Hg7cpQ5EwtIgS_BlppkgC7NL7kEn693DxFyoDH6e0ufPYsiNgBU37BJMJwSVUOKcJBERw

Modeling the interaction between flooding events and economic growth-ScienceDirect. (n.d.). Retrieved April 3 2021, from https://www.sciencedirect.com/science/article/pii/S0921800915303980

Mechler, R. (2016). Reviewing estimates of the economic efficiency of disaster risk management: Opportunities and limitations of using risk-based cost-benefit analysis. Natural Hazards, 81(3), 2121-2147.

Parida, Y. (2020). Economic impact of floods in the Indian states. Environment and Development Economics, 25(3), 267-290.

Financing Disaster Management: Options for the GST Council and the Fifteenth Finance Commission | Economic and Political Weekly. (n.d.). Retrieved April 3 2021, from https://www.epw.in/journal/2019/25/special-articles/financing-disaster-management.html

Jain, A., Goyal, R., Singh, S., \& Pradhan, L. (2016). Municipal solid waste management in India: A case study of post consumed tetra pak cartons in Delhi.

Waza, Mehraj Ud Din, and Sonam Sharma. 2018. 'Preparedness and Response to Disasters: A Case of 2014 Floods in Jammu City'. International Journal of Research in Social Sciences 8(3): 111-21.

Bhambri, R., Hewitt, K., Kawishwar, P., Kumar, A., Verma, A., Snehmani, Tiwari, S., \& Misra, A. (2019). Ice-dams, outburst floods, and movement heterogeneity of glaciers, Karakoram. Global and Planetary Change, 180. https://doi.org/10.1016/j.gloplacha.2019.05.004

Bhambri, R., Hewitt, K., Kawishwar, P., Kumar, A., Verma, A., Snehmani, Tiwari, S., \& Misra, A. (2019). Ice-dams, outburst floods, and movement heterogeneity of glaciers, Karakoram. Global and Planetary Change, 180. https://doi.org/10.1016/j.gloplacha.2019.05.004

Dewan, A. M. (2013). Hazards, Risk, and Vulnerability. In A. Dewan (Ed.), Floods in a Megacity: Geospatial Techniques in Assessing Hazards, Risk and Vulnerability (pp. 35-74). Springer Netherlands. https://doi.org/10.1007/978-94-007-5875-9 2

Brent, R. J. (2006). Applied cost-benefit Analysis (2nd ed). Edward Elgar.

Evaluation of impacts of climate change and human activities on streamflow in the Poyang Lake basin, China-Zhang-2016-Hydrological Processes-Wiley Online Library. (n.d.).

Retrieved March 25 2021, from https://onlinelibrary.wiley.com/doi/abs/10.1002/hyp.10814

Bansal, D. N. (2017). Causes and Effect of Kashmir Flood. 7.

Jammu and Kashmir was unprepared for flood fury. (n.d.). Retrieved March 3 2021, from https://www.downtoearth.org.in/news/jammu-and-kashmir-was-unprepared-for-flood-fury$\underline{46233}$ 
Sandrp. (2015, July 6). Dams, Rivers \& People News Bulletin, July 06, 2015. SANDRP. https://sandrp.in/2015/07/06/dams-rivers-people-news-bulletin-july-06-2015/

The 2014 Kashmir Flood: The Extreme of the Extremes. (2015, March 14). Greater Kashmir. https://www.greaterkashmir.com/news/gk-magazine/the-2014-kashmir-flood-the-extreme-ofthe-extremes/

Yatoo, I. A., Chourey, Prof. B., \& Aalum, K. (2018). A Brief Survey on Impact of Flood on Children, Water Sanitation and Hygiene in Kashmir Valley. International Journal of Engineering and Management Research, 8(5). https://doi.org/10.31033/ijemr.8.5.1

All Hazards Risk Assessment Methodology Guidelines 2012-2013. (2018, December 21). https://www.publicsafety.gc.ca/cnt/rsrcs/pblctns/ll-hzrds-ssssmnt/index-en.aspx

World Meteorological Organization. (n.d.). World Meteorological Organization. Retrieved February 10 2021, from https://public.wmo.int/en

Disaster Management | District Kulgam, Government of Jammu and Kashmir,Picturesque place nestling on the bank of river Veshaw|India. (n.d.). Retrieved March 29 2021, from https://kulgam.nic.in/disaster-management/

Official website of Kashmir Irrigation and Flood Control Department, Srinagar. (n.d.). Retrieved March 29 2021, from https://www.ifckashmir.com/

Botzen, W. J. W., Monteiro, É., Estrada, F., Pesaro, G., \& Menoni, S. (2017). Economic Assessment of Mitigating Damage of Flood Events: Cost-Benefit Analysis of Flood-Proofing Commercial Buildings in Umbria, Italy. The Geneva Papers on Risk and Insurance - Issues and Practice, 42(4), 585-608. https://doi.org/10.1057/s41288-017-0065-0

Negative socioeconomic Impacts of Floods: E-Learning Platform for IFM. (n.d.). Retrieved April 3 2021, from http://daad.wb.tu-harburg.de/tutorial/integrated-flood-management-ifm-policyand-planning-aspects/social-aspects-and-stakeholder-involvement/social-aspects/negativesocio-economic-impacts-of-floods/

Associated Programme on Flood Management, World Meteorological Organization, \& Global Water Partnership (Eds.). (2007). Economic aspects of integrated flood management. Associated Programme on Flood Management. 